\title{
Protein-calorie deficiency in rats
}

\author{
Growth and reproduction \\ By R. J. C. STEWART AND HILDA G. SHEPPARD \\ Department of Human Nutrition, London School of Hygiene and \\ Tropical Medicine, London
}

(Received 29 June 1970-Accepted I3 August 1970)

\begin{abstract}
I. Rats born of well-fed mothers and maintained from weaning on diets having protein values of NDpCal \% = Io or 5 were mated at 3 months of age with well-fed males.

2. The litters produced by the malnourished mothers weighed significantly less $(P<0.01)$ than those from the well-fed group.

3. The average number of individuals per litter was lower in the malnourished than in the well-fed group, but the difference was not statistically significant $(P>0.05)$.

4. The congenitally malnourished litters weighed less than the well-fed even when litters of equal number were compared.

5. The differences in litter weights were not related to the length of gestation, which was similar in both groups.

6. There was a high neonatal death rate $(63 \%)$ among the congenitally malnourished animals and the survivors grew very slowly so that at 5 weeks of age they weighed only half as much as the well-fed controls.
\end{abstract}

Reports from various parts of the world indicate that women within the lower socio-economic groups produce babies of low birth weight more often than mothers of similar race in the higher socio-economic groups. Suggested explanations for this finding have included the stature of the mother, complications of pregnancy and poor nutrition. If one accepts stature as the limiting factor, then it is natural to ask why women in low socio-economic groups are shorter than those in higher groups, and the suggestion of Thomson \& Billewicz (1963) that this is an indication of longcontinued dietary practices may provide the answer. Burke, Beal, Kirkwood \& Stuart (1943) have claimed that the common complications of pregnancy are also more frequent in women of low income groups and have related this, as well as the poor quality of their offspring, to poor nutrition. Nutritional effects are, however, discounted by other workers, who believe that a severely malnourished woman will not conceive and that a less severely affected woman who is able to conceive will sacrifice her own tissues to provide adequate food supplies for her young. On the basis of experiments with dogs, Platt \& Stewart (1967a, 1968) suggested that, although the mother was able to protect her offspring against the effects of mild malnutrition, more severe deficiencies were shared and the degree of protection given to the young was controlled by the mother's nutritional state when she entered pregnancy.

It had been hoped to maintain colonies of dogs for several generations to test the long-term effects of mild dietary deficiencies but, because of difficulties in accommodation, the work with dogs had to be discontinued and the present report describes an attempt to transfer the investigation to rats. 


\section{EXPERIMENT AL}

A stock"colony of black and white rats was maintained at the Nutrition Building, National Institute for Medical Research, for several years. The animals were housed in wire mesh cages in rooms maintained at $25^{-2} 7^{\circ}$, with unlimited access to Oxoid cubes (H. C. Styles (Bewdley) Ltd, Worcestershire) and tap-water. During pregnancy and lactation each mother had her own cage with an ample supply of wood-wool for nest building.

Female young were separated from their mothers at 3 weeks of age and given diets similar to those used for dogs (Table I) (Platt \& Stewart, I968). One-third of these were given the ' $0-10$ ' diet and two-thirds the ' $0-5$ '; other conditions were as for the stock colony. The young males were given the stock diet.

\section{Table 1 . Percentage composition of the diets}

\begin{tabular}{|c|c|c|}
\hline Ingredient & $\begin{array}{c}\text { Diet } \\
\text { O-Io* }\end{array}$ & $\begin{array}{l}\text { Diet } \\
0-5^{*}\end{array}$ \\
\hline Rolled oats (Quaker Oats Ltd) & 45 & 45 \\
\hline Dripping (beef) & 25 & 25 \\
\hline Casein & 22 & 4 \\
\hline Maize starch & 3 & $2 I$ \\
\hline Salt mixture (Jones \& Foster, 1942) & $\begin{array}{l}3 \\
4\end{array}$ & 4 \\
\hline Mixture of $\mathrm{B}$ vitamins $\dagger$ & I & I \\
\hline Fat-soluble vitamins $\ddagger$ & + & + \\
\hline Protein values of the diets in NDpCal \% & $9 \cdot 8$ & $5 \cdot 2$ \\
\hline
\end{tabular}

\footnotetext{
* Code names for diets with oats as the main ingredient.

+ Contained thiamin hydrochloride $0.3 \mathrm{mg}$, riboflavin $1.0 \mathrm{mg}$, pyridoxine hydrochloride $0.2 \mathrm{mg}$, calcium pantothenate $6 \mathrm{mg}$, nicotinic acid $20 \mathrm{mg}$, $m y o$-inositol $20 \mathrm{mg}, p$-aminobenzoic acid $60 \mathrm{mg}$, biotin $0.02 \mathrm{mg}$, pteroylmonoglutamic acid $0.2 \mathrm{mg}$, choline $60 \mathrm{mg}$, cyanocobalamin $5 \mu \mathrm{g}$.

$\ddagger$ Each rat received from weaning 800 i.u. retinol, 40 i.u. ergocalciferol, $1 \cdot 25 \mathrm{mg}$ mixed tocopherols and $0.08 \mathrm{mg}$ menaphthone each week.
}

The malnourished females were not sufficiently mature to breed before the age of 3 months, at which time males were introduced into the cages of both the ' $0-10$ ' and ' $0-5$ ' groups (one male to five females). In many tests the males were removed after I $6 \mathrm{~h}$ (overnight) and gestation times were calculated from the time of removal. In other experiments the appearance of mating plugs was accepted as the beginning of pregnancy. Parturition could not always be accurately timed so that discrepancies of some hours could occur at both the beginning and end of the period. In spite of this, the gestation times were all within $2 \mathrm{I}-23 \mathrm{~d}$ with no discernable differences between the groups. The litters produced were weighed as soon as possible after birth and any not weighed within $16 \mathrm{~h}$ were used only for weights at 4 or 5 weeks of age. All large litters were reduced to eight individuals. As the congenitally malnourished young were small and weak, none of the experimental rats was weaned until the $4^{\text {th }}$ or $5^{\text {th }}$ week of age. To avoid extra handling of the young, which appeared to encourage abandonment and cannibalism by the deficient mothers, weighing of individuals was not attempted before weaning. Food intakes were not measured but the smaller animals maintained on the deficient diet $(0-5)$ certainly ate less food than did well-grown age controls (o-10). 
RESULTS

The average weights of the 3 -month-old females used for breeding were $190 \mathrm{~g}$ (SE I.5) for those of the 'O-IO' group and $127 \mathrm{~g}$ (SE 2.3) for those on the diet of low protein value, a difference which is highly significant $(P<0.001, n=263)$.

Many of the deficient animals failed to conceive, and resorptions were more common than in the ' $O-10$ ' group. Thus sixty-seven litters (504 young) were born to the mothers on the diets of high protein value and seventy-six litters (502 young) to the larger group on the protein-calorie deficient regimen.

Table 2. Average birth weights and numbers in litters born to rats maintained on diets of adequate (0-10) or of low (0-5) protein value

\begin{tabular}{|c|c|c|c|c|c|c|c|}
\hline \multirow{2}{*}{$\begin{array}{c}\text { Mothers' } \\
\text { diets }\end{array}$} & \multirow{2}{*}{$\begin{array}{l}\text { Total } \\
\text { litters }\end{array}$} & \multirow{2}{*}{$\begin{array}{l}\text { Total } \\
\text { young }\end{array}$} & \multicolumn{2}{|c|}{$\begin{array}{l}\text { Average wt } \\
\text { of litter }\end{array}$} & \multicolumn{2}{|c|}{ No. in litter } & \multirow{2}{*}{$\begin{array}{l}\text { Average wt } \\
\text { of indi- } \\
\text { viduals } \\
\text { (g) }\end{array}$} \\
\hline & & & $\mathrm{g}$ & SE & Average & $\mathrm{SE}$ & \\
\hline $0-10$ & 67 & 504 & $4 I \cdot 6$ & I.94* & $7 \cdot 5$ & $0.36 \dagger$ & $5 \cdot 5$ \\
\hline $0-5$ & 76 & 502 & $32 \cdot 7$ & $1 \cdot 46^{*}$ & $6 \cdot 6$ & $0.30 \dagger$ & $4 \cdot 9$ \\
\hline
\end{tabular}

Table 3. Average birth weights of litters relative to number in litters born to rats maintained on diets of adequate (0-10) or of low (0-5) protein value

\begin{tabular}{|c|c|c|c|c|}
\hline \multirow[b]{2}{*}{$\begin{array}{l}\text { No. in } \\
\text { litter }\end{array}$} & \multicolumn{2}{|c|}{ Mothers' diet o-io } & \multicolumn{2}{|c|}{ Mothers' diet o-5 } \\
\hline & $\begin{array}{l}\text { No. of } \\
\text { litters }\end{array}$ & Average wt (g) & $\begin{array}{l}\text { No. of } \\
\text { litters }\end{array}$ & Average wt $(\mathrm{g})$ \\
\hline I & - & - & 2 & $4: 3$ \\
\hline 2 & 4 & II 8 & 2 & $9 \circ 0$ \\
\hline 3 & 4 & 15.7 & 7 & $14 \cdot 9$ \\
\hline 4 & 5 & $24 \cdot 6$ & 8 & $2 I \cdot 3$ \\
\hline 5 & 7 & $28 \cdot 4$ & 6 & $26 \cdot 6$ \\
\hline 6 & 3 & 34.9 & 7 & $30 \cdot 5$ \\
\hline 7 & 6 & $39 \cdot 8$ & 16 & $34 \cdot 3$ \\
\hline 8 & 13 & $44 \cdot 5$ & 12 & $39 \cdot 9$ \\
\hline 9 & 6 & $50 \cdot 0$ & 4 & $41 \cdot 7$ \\
\hline ro & 6 & $55^{\cdot 1}$ & 7 & $48 \cdot 6$ \\
\hline II & 8 & $60 \cdot 7$ & 3 & 53.5 \\
\hline 12 & 3 & $6 \pi \cdot 7$ & 2 & $56 \cdot 8$ \\
\hline I3 & I & $68 \cdot 5$ & 0 & - \\
\hline 14 & I & $6 \mathrm{r} \cdot 0$ & o & - \\
\hline
\end{tabular}

The litter weights averaged $4 \mathrm{I} \cdot 6 \mathrm{~g}$ for the ' $\mathrm{O}-1 \mathrm{O}^{\prime}$ ' group, and $32 \cdot 7 \mathrm{~g}$ for the ' $0-5^{\prime}$ ', a difference which is significant at the $\mathrm{I} \%$ level. The average numbers of rats per litter were 7.5 and 6.6 respectively, a difference which failed to reach the $5 \%$ level of significance (Table 2). Litters containing an average of 7.5 young would, however, be expected to weigh more than those containing $6 \cdot 6$, and Table 3 shows the distribution of litter size and the average weights for litters containing equal numbers of young. The litters from the protein-calorie deficient animals consistently weighed less than those from the control group. The regression lines of litter weight on litter size are approximately linear and parallel ( 4.69 and 4.68$)$, with a highly significant difference in their inter- 
cepts $(P<0.001)$. All the young in the underweight litters appeared to be affected and the number of 'runts' was not excessive. As there were no differences in the lengths of the gestation periods, the young must be regarded as small-for-dates rather than premature. The heads of the rats from the deficient mothers were relatively large and this disparity appeared to increase during the first few weeks of life (P1. I).

Many of the congenitally malnourished animals died within 2 or 3 weeks of birth and others which were very weak or had been abandoned by their mothers were killed to obtain material for histological and chemical examination. Only $37 \%$ of the young left with the females at birth survived to 5 weeks of age. In the high-protein group, deaths and abandonments were fewer; some animals were killed to provide control material but $68 \%$ were alive at 5 weeks. At this time the weight difference between the two groups was very large and a significant difference in the average weights of the normal males and females became apparent, but this did not occur in the deficient group (Table 4 ).

Table 4. Average weights, at 4 and 5 weeks of age, of rats born of and suckled by mothers maintained on diets of adequate (0-10) or of low (0-5) protein value

\begin{tabular}{|c|c|c|c|c|c|c|c|}
\hline \multirow[b]{2}{*}{$\begin{array}{c}\text { Age } \\
\text { (weeks) }\end{array}$} & \multirow[b]{2}{*}{ Sex } & \multicolumn{3}{|c|}{ Diet o-10 } & \multicolumn{3}{|c|}{ Diet $0-5$} \\
\hline & & No. & $\begin{array}{c}\text { Wt } \\
(\mathrm{g})\end{array}$ & $\mathrm{SE}$ & No. & $\begin{array}{l}W \mathrm{t} \\
\text { (g) }\end{array}$ & SE \\
\hline 4 & $\begin{array}{l}\hat{o}^{x} \\
q \\
0^{x}+q\end{array}$ & $\begin{array}{l}4 \mathrm{I} \\
4 \mathrm{O} \\
8 \mathrm{I}\end{array}$ & $\begin{array}{l}70 \cdot 5 \\
68 \cdot 2 \\
69 \cdot 4\end{array}$ & $\begin{array}{l}1.21 \\
1.82 \\
1.02\end{array}$ & $\begin{array}{l}55 \\
39 \\
94\end{array}$ & $\begin{array}{l}32 \cdot 6 \\
33 \cdot 0 \\
32 \cdot 8\end{array}$ & $\begin{array}{l}\mathrm{I} \cdot 33 \\
\mathrm{r} \cdot 87 \\
\mathrm{I} \cdot \mathrm{I} 4\end{array}$ \\
\hline 5 & $\begin{array}{l}0 \\
q \\
o \\
0+q\end{array}$ & $\begin{array}{l}133 \\
153 \\
286\end{array}$ & $\begin{array}{l}96 \cdot 7 \\
86 \cdot 6 \\
9 \pi \cdot 3\end{array}$ & $\begin{array}{l}1.69 \\
1.40 \\
1.08\end{array}$ & $\begin{array}{r}70 \\
85 \\
155\end{array}$ & $\begin{array}{l}47^{\circ} \text { I } \\
44^{\circ} 9 \\
45^{\circ} 9\end{array}$ & $\begin{array}{l}\mathrm{I} \cdot 52 \\
\mathrm{I} \cdot 42 \\
\mathrm{I} \cdot 08\end{array}$ \\
\hline
\end{tabular}

All the differences between animals on the $0-10$ and $0-5$ diets are highly significant $(P<0.001)$, those between males and females on similar diets are significant $(P<0.01)$ only for the 5-week-old animals on the $0-10$ diet.

\section{DISCUSSION}

The experiments were started in the expectation of maintaining one group of rats on an adequate diet and another on a suboptimal diet for several generations, but in this respect it failed. The heavy mortality amongst the congenitally malnourished group would have necessitated a very large colony of breeding does and, as the diets shown in Table I could not be commercially 'cubed', the labour costs were prohibitive.

The results of this preliminary experiment indicate, however, that the low birth weights and poor rates of growth found in congenitally malnourished dogs also occur in rats. The protein value of the diet used $(\mathrm{NDpCal} \%=5)$ was slightly lower than that used for the deficient dogs ( $\mathrm{NDpCal} \%=7)$ and this may have caused the slightly greater neonatal loss. The lack of a significant effect on the average number in the litters was surprising, for in earlier work, admittedly with relatively few rats, it was thought that resorptions were increased and that the number of young per litter was reduced to a greater extent than individual weights (El-Maraghi, Platt \& Stewart, 1966). This was in keeping with the work of Gupta \& Christie (1968) who showed that the pre-implantation losses and the number of resorptions were increased in rats fed 
on the ' $0-5$ ' diet. A reduced litter size would also be expected from the work of Kinzey $\&$ Srebnik (1963) with protein-free diets and from the known effects of protein-calorie deficiency on the endocrine glands (Platt \& Stewart, 1967 $b$; Heard \& Stewart, 1970). This discrepancy requires further investigation.

Rats maintained on adequate diets until conception and then given diets of low protein value ( $\mathrm{NDpCal} \%=5.9$; Naismith, 1966) produced young of normal weight and composition and this was attributed to 'parasitism', whereby the young obtained all required nutrients at the expense of the mother. This did not occur in our experiments in which the females were protein-calorie deficient from weaning and, as suggested for dogs (Platt \& Stewart, 1968), the gestational deficiencies were shared. Birth weights can also be reduced by restricting the food intake of pregnant rats but, to obtain reductions similar to those reported above, the intake has to be reduced by 25 or 50\% (Chow \& Lee, r964; Berg, 1965). These 'calorie restricted' rats are said to remain small even when well-fed after weaning (Chow, Blackwell, Blackwell, Hou, Anilane \& Sherwin, 1968).

Various workers (Dobbing \& Widdowson, r965; Barnes, Cunnold, Zimmermann, Simmons, MacLeod \& Krook, r966; Frañková, 1968; Guthrie \& Brown, 1968) have shown that rats given inadequate supplies of milk (e.g. large numbers suckled by one doe) exhibit differences in behaviour and brain chemistry. The animals in the present investigation were also underfed during suckling, not because the numbers per litter were large, but because of the relative inactivity of the mammary glands of animals reared and maintained on protein-calorie deficient regimens (Platt, Heard \& Stewart, 1964; Platt \& Stewart, 1968). Although some abnormal head and limb movements have been recorded, the frank neurological symptoms reported in congenitally malnourished dogs have not been seen in the rats, but differences in behaviour, brain size and morphology have been observed (in preparation).

It is hoped that a modified 'cubed' diet at present in use will allow these observations to be continued for several generations and to indicate any problems which might arise when such long-term deficiencies are corrected.

The rat and dog experiments indicate, therefore, that females maintained throughout life on diets of poor protein value might be expected to produce young which are underweight for their race or strain, are prone to early death, grow very slowly, exhibit some behavioural changes and become small adults.

We thank Miss E. F. Wheeler for advice on statistical methods and Miss M. Harrison for her help in caring for the animals.

\section{REFERENCES}

Barnes, R. H., Cunnold, S. R., Zimmermann, R. R., Simmons, H., MacLeod, R. B. \& Krook, L. (I966). F. Nutr. 89, 399.

Berg, B. N. (1965). J. Nutr. 87, 344.

Burke, B. S., Beal, V. A., Kirkwood, S. B. \& Stuart, H. C. (1943). Am. F. Obstet. Gynec. 46, 38.

Chow, B. F., Blackwell, R. Q., Blackwell, B.-N., Hou, T. Y., Anilane, J. K. \& Sherwin, R. W. (I968). Am. F. publ. Hlth 58, 668 .

Chow, B. F. \& Lee, C-J. (1964). F. Nutr. 82, 10.

Dobbing, J. \& Widdowson, E. M. (1965). Brain 88, 357.

El-Maraghi, N. R. H., Platt, B. S. \& Stewart, R. J. C. (r966). Br. F. Nutr. 20, 733. 
Frañková, S. (1968). In Malnutrition, Learning and Behavior p. 3 12 [N. S. Scrimshaw and J. E. Gordon, editors]. Cambridge, Massachusetts: M.I.T. Press.

Gupta, S. R. \& Christie, B. (I968). Indian F. med. Res. 56, I 14.

Guthrie, H. A. \& Brown, M. L. (I968). F. Nutr. 94, 419.

Heard, C. R. C. \& Stewart, R. J. C. (1970). Hormones (In the Press.)

Jones, J. H. \& Foster, C. (1942). F. Nutr. 24, 245.

Kinzey, W. G. \& Srebnik, H. H. (1963). Proc. Soc. exp. Biol. Med. I14, I 58.

Naismith, D. J. (1966). Metabolism 15, 582.

Platt, B. S., Heard, C. R. C. \& Stewart, R. J. C. (1964). In Mammalian Protein Metabolism Ch. 21, p. 445 [H. N. Munro and J. B. Allison, editors]. New York and London: Academic Press Inc.

Platt, B. S., Miller, D. S. \& Payne, P. R. (1961). In Recent Advances in Clinical Nutrition p. 35 [J. F. Brock, editor]. London: J. \& A. Churchill.

Platt, B. S. \& Stewart, R. J. C. (1967a). Maternal and Child Care 3, 539.

Platt, B. S. \& Stewart, R. J. C. (1967b). F. Endocr. 38, I21.

Platt, B. S. \& Stewart, R. J. C. (1968). Devl Med. Child. Neurol. ro, 3.

Thomson, A. M. \& Billewicz, W. Z. (1963). Proc. Nutr. Soc. 22, 55.

\section{EXPLANATION OF PLATE}

Photographs of two 8-month-old rats maintained from weaning on diet o-10, of adequate protein value, (A) or $0-5$, of low protein value, (B) and of their $16-d-o l d$ offspring (C) and (D) respectively. Note : (1) At 8 months of age the difference in size is not large; (2) very large difference in body size of offspring, and $(3)$ in (D) the relatively large head. 

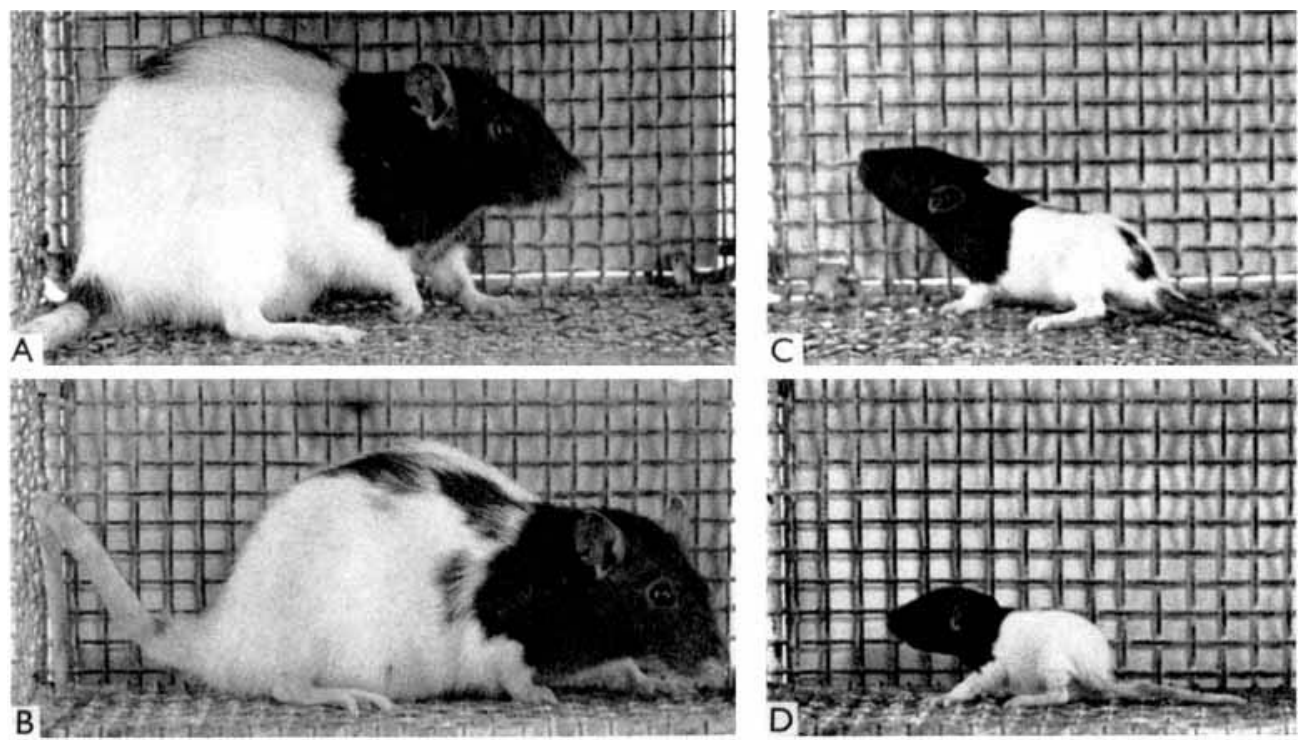